\title{
Evaluasi Kinerja Penyediaan Air Bersih di Kelurahan Baru Ulu, Kecamatan Balikpapan Barat, Kota Balikpapan
}

\author{
Evaluation of Performance of Clean Water Supply in Kelurahan Baru Ulu, Kecamatan \\ Balikpapan Barat, Balikpapan City
}

Risa Andini ${ }^{1 *}$, Mega Ulimaz ${ }^{1}$, Sulistijono ${ }^{2}$

${ }^{1}$ Program Studi Perencanaan Wilayah dan Kota, Jurusan Teknik Sipil dan Perencanaan, Institut Teknologi Kalimantan, Jl. Soekarno-Hatta Km. 15, Karang Joang, Balikpapan, Kalimantan Timur, 76127; ${ }^{2}$ Program Studi Teknik Material dan Metalurgi, Jurusan Ilmu Kebumian dan Lingkungan, Institut Teknologi Kalimantan, Jl. Soekarno-Hatta Km. 15, Karang Joang, Balikpapan, Kalimantan Timur, 76127;

*Penulis korespondensi. $e$-mail: risandn@gmail.com

(Diterima: 24 Juli 2017; Disetujui: 3 Januari 2018)

\begin{abstract}
Kelurahan Baru Ulu is a coastal area in Kecamatan Balikpapan Barat. This area is dominated by the settlement activities; therefore, it relies on high demand of clean water. However, the society's need of clean water that lives in this area is not fulfilled completely. This research aims on evaluating the performance of supplying clean water in the mentioned area using the Importance Performance Analysis so that the result of this research will be the main indicator in fulfilling clean water supply at Kelurahan Baru Ulu. According to the analysis, the indicators of clean water supply which has the high importance followed by the low performance are the bacterial substance, saltiness, smell in the water, water discharge, amount of water from the source, duration of water flowing per day, water supply in the morning, and residents' agreement on water tariff.
\end{abstract}

Keywords: importance performance analysis, evaluation, coastal area, clean water supply, importance level, performance level

\begin{abstract}
ABSTRAK
Kelurahan Baru Ulu merupakan kawasan pesisir di Kecamatan Balikpapan Barat. Kawasan ini didominasi oleh kegiatan permukiman, sehingga tidak lepas dari kebutuhan air bersih yang tinggi. Namun, kebutuhan air bersih masyarakat yang tinggal di kawasan ini belum sepenuhnya terpenuhi. Penelitian ini bertujuan untuk mengevaluasi kinerja penyediaan air bersih di wilayah tersebut menggunakan Importance Performance Analysis agar nantinya hasil yang didapatkan bisa menjadi indikator yang diutamakan dalam pemenuhan kebutuhan air bersih di Kelurahan Baru Ulu. Berdasarkan hasil analisis, indikator penyediaan air bersih yang memiliki kepentingan tinggi disertai kinerja penyediaan yang rendah meliputi kandungan bakteri dalam air, rasa asin pada air, bau pada air, deras air mengalir, banyaknya jumlah air dari sumbernya, durasi air mengalir dalam satu hari, ketersediaan air pada pagi hari, dan persetujuan masyarakat mengenai tarif air.

Kata kunci: analisis kepentingan dan kinerja, evaluasi, kawasan pesisir, penyediaan air bersih, tingkat kepentingan, tingkat kinerja.
\end{abstract}




\section{PENDAHULUAN}

Kelurahan Baru Ulu merupakan kelurahan yang menjadi bagian dari kawasan pesisir Kota Balikpapan. Kelurahan ini terletak di Kecamatan Balikpapan Barat, dan menjadi bagian dari area Teluk Balikpapan. Kelurahan Baru Ulu mempunyai luas wilayah sebesar 95 hektar, yang merupakan Kelurahan terluas nomor dua di Kecamatan Balikpapan Barat (BPS Kota Balikpapan, 2016). Jenis penggunaan lahan terbanyak di Kelurahan Baru Ulu adalah permukiman, yakni sebesar 81,04 hektar dengan persentase $85 \%$ dari luas wilayah kelurahan (Badan Perencanaan dan Pembangunan Balikpapan, 2016). Berdasarkan hal tersebut, kelurahan tersebut tidak luput dari tingginya kebutuhan air bersih sebagai penunjang kehidupan masyarakat.

Kelurahan Baru Ulu memiliki sebaran air tanah yang kurang produktif dibandingkan dengan wilayah lain di Kota Balikpapan (PDAM Kota Balikpapan, 2004). Berdasarkan data dari BPS Kota Balikpapan tahun 2016, penggunaan sumur pompa baik dalam maupun dangkal berkisar 6\% dari jumlah keseluruhan pengguna air bersih. Pada area yang memiliki elevasi rendah terhadap permukaan laut, masyarakat dapat memanfaatkan air yang terdapat di bawah permukaan tanah. Namun, pada area yang memiliki elevasi tinggi terhadap permukaan laut, masyarakat tidak dapat memanfaatkan air yang terdapat di bawah permukaan tanah karena ketersediaannya yang minim di area tersebut. Sifat fisik wilayah yang berupa kawasan pesisir juga cukup menyulitkan PDAM Kota Balikpapan untuk menjangkau permukiman lebih jauh. Oleh karena itu, diperlukan upaya keterlibatan masyarakat dalam penyediaan air bersih. Suatu program penyediaan air minum, sanitasi, dan kesehatan akan efektif dan berkelanjutan bila berbasis pada masyarakat melalui pelibatan seluruh masyarakat (Afrilya \& Rahmawati, 2014).

Sementara itu, berdasarkan wawancara dengan tokoh masyarakat setempat, untuk memenuhi kebutuhan air bersih, masyarakat
Kelurahan Baru Ulu melakukan beberapa upaya. Upaya-upaya tersebut di antaranya dengan membuat sumur permukaan, membeli air bersih per tangki dari PDAM dan swasta, serta menampung air hujan. Tiga upaya tersebut dilakukan oleh masyarakat Kelurahan Baru Ulu untuk memenuhi kebutuhan air bersih mereka masing-masing dan masih dilakukan serta digunakan secara pribadi individu. Dapat diidentifikasi permasalahan sebagai berikut:

a. Kelurahan Baru Ulu didominasi oleh kegiatan bermukim, sehingga membutuhkan air bersih sebagai salah satu penunjang utama kegiatan masyarakat.

b. Kelurahan Baru Ulu merupakan wilayah pesisir yang memiliki potensi air bersih yang rendah berdasarkan kondisi fisik wilayahnya.

Dalam kinerja penyediaan air bersih, kualitas air bersih menjadi penting mengingat sumber daya air merupakan salah satu sumber daya alam yang paling banyak digunakan oleh masyarakat untuk mendukung kehidupan seharihari. Untuk melihat kualitas air bersih, terdapat beberapa indikator, di antaranya adalah kekeruhan air, kandungan bahan organik dalam air, kandungan garam dalam air, kandungan zat besi dalam air, $\mathrm{pH}$ air, dan indikator biologi air (Lestari et al, 2009).

Penyediaan air minum harus dapat memenuhi setiap segi kehidupan masyarakat dan tersedia dalam jumlah yang cukup baik untuk disalurkan secara terus menerus maupun untuk jam-jam tertentu. Pengukuran kuantitas air bersih dapat dilakukan dengan melihat debit air bersih. Debit air terkait dengan ketersediaan air baku. Jika debit air makin lama makin berkurang, ini bisa menjadi indikator atau tanda bahwa ketersediaan air berkurang (Lestari et al, 2009). Menurut Yuliani dan Rahdriawan (2014), menilai kuantitas air dapat dilihat dengan melihat banyaknya air yang didapat setiap bulan.

Menurut Sinulingga (2013), kontinuitas air bersih juga diartikan bahwa air bersih harus tersedia 24 jam per hari, atau setiap saat diperlukan, kebutuhan air tersedia. Untuk menentukan tingkat kontinuitas pemakaian air dapat dilakukan dengan cara pendekatan 
aktifitas konsumen terhadap prioritas pemakaian air. Prioritas pemakaian air yaitu minimal selama 12 jam per hari, yaitu pada jam-jam aktifitas kehidupan, yaitu pada pukul 06.00 - 18.00.

Terdapat beberapa elemen yang memengaruhi keberlanjutan sistem penyediaan air bersih, meliputi kelembagaan, pengembangan keahlian, perilaku masyarakat yang mendukung, pengembangan pelayanan masyarakat, tingkat pelayanan, dan teknologi (Mwakila, 2008).

Berdasarkan penjabaran tersebut, perlu adanya evaluasi kinerja penyediaan air bersih di Kelurahan Baru Ulu, yang bertujuan untuk mengetahui penilaian masyarakat mengenai tingkat kinerja dan tingkat kepentingan indikator. Sehingga dapat diketahui indikator apa saja yang memiliki kinerja rendah dengan kepentingan tinggi, yang nantinya dapat dijadikan prioritas dalam upaya pemenuhan kebutuhan air bersih di kawasan tersebut.

\section{METODOLOGI}

Metode pengumpulan data dalam penelitian ini didapatkan melalui survei primer. Survei primer merupakan pengumpulan data secara langsung, dengan melakukan penyebaran kuesioner langsung di Kelurahan Baru Ulu. Dalam penelitian ini, daftar pertanyaan disusun berdasarkan indikator kinerja penyediaan air bersih. Kemudian untuk mendapatkan jawaban dari pertanyaan yang didasarkan atas penetapan indikator tersebut dari para responden, dilakukan penyebaran daftar pertanyaan yang sifatnya tertutup. Kuesioner dilakukan untuk memenuhi penilaian tingkat kinerja dan tingkat kepentingan penelitian ini.

Teknik penentuan sampel responden kuesioner yang digunakan adalah dengan teknik non probability sampling. Prinsip-prinsip probability tidak dihiraukan. Pemilihan sampel tidak secara random. Hasil yang diharapkan merupakan gambaran keseluruhan mengenai penggunaan penyediaan air bersih di Kelurahan Baru Ulu.

Pengambilan sampel dilakukan menggunakan metode purposive sampling.
Pengambilan sampel dilakukan hanya atas dasar pertimbangan saja yang menganggap unsurunsur yang dikehendaki telah ada dalam anggota sampel yang diambil, yakni dengan mengambil sampel dari tiap bentuk penggunaan penyediaan air bersih yang ada di Kelurahan Baru Ulu meliputi bentuk penyediaan berupa jaringan perpipaan PDAM, sumur pompa, dan sumur gali. Populasi dalam penelitian ini adalah jumlah Kartu Keluarga yang ada di Kelurahan Baru Ulu. Hal tersebut didasari oleh asumsi bahwasanya satu KK merupakan satu bangunan rumah tinggal. Berdasarkan Badan Pusat Statistik Kota Balikpapan dalam publikasi berjudul Kecamatan Balikpapan Barat dalam Angka 2016, jumlah keseluruhan KK di Kelurahan Baru Ulu sebanyak 8.035 KK. Pada penelitian ini, penentuan jumlah sampel dilakukan berdasarkan Rumus Slovin, dengan toleransi kesalahan $10 \%$. Berdasarkan hasil perhitungan, didapat bahwa jumlah sampel responden adalah 99 Kartu Keluarga (KK) di Kelurahan Baru Ulu. Dengan dilakukan pengisian satu kuesioner diisi oleh satu orang yang mewakili satu Kartu Keluarga (KK).

Evaluasi kinerja penyediaan air bersih dilakukan dengan Analisis Importance Performance Analysis atau disebut analisis IPA. Analisis IPA merupakan suatu metode analisis yang merupakan kombinasi antara aspek-aspek tingkat kepentingan dan persepsi terhadap kualitas atau kondisi suatu objek ke dalam bentuk dua dimensi (Arimbi, 2015).

Importance Performance Analysis (Analisis IPA) merupakan alat bantu dalam menganalisis atau yang digunakan untuk membandingkan sampai sejauh mana antara kinerja yang dapat dirasakan oleh pengguna sistem penyediaan air bersih yang ada di Kelurahan Baru Ulu dibandingkan terhadap tingkat kinerja yang diinginkan. Tingkat kesesuaian merupakan hasil perbandingan antara skor kinerja pelaksanaan dengan skor kepentingan, sehingga tingkat kesesuaian inilah yang akan menentukan skala prioritas yang akan dipakai dalam indikator penyediaan air bersih yang mempengaruhi kinerja masyarakat Kelurahan Baru Ulu. 
1. Tingkat Kepentingan (Importance)

Sebagai pedoman bagi masyarakat Kelurahan Baru Ulu untuk menilai tingkat kepentingan indikator penyediaan air bersih, digunakan skala dengan nilai 1-5.

1: Sangat Tidak Penting

2: Tidak Penting

3: Cukup Penting

4: Penting

5: Sangat Penting

2. Tingkat Kinerja (Performance)

Sebagai pedoman bagi konsumen untuk menilai tingkat kinerja layanan, juga digunakan skala dengan nilai 1-5.

1: Sangat Tidak Puas

2: Tidak Puas

3: Cukup Puas

4: Puas

5: Sangat Puas

Adapun tahapan metode analisis IPA adalah sebagai berikut:

1. Pembobotan

Skala yang digunakan dalam penelitian ini adalah skala likert. Skala likert umumnya digunakan dalam penelitian yang bersifat pengukuran sikap, keyakinan, nilai dan pendapat pengguna atau konsumen terhadap suatu kondisi objek.

2. Analisis Kuadran

Langkah pertama untuk analisis kuadran adalah menghitung rata-rata penilaian kepentingan dan kinerja untuk setiap atribut dengan rumus:

$$
\begin{gathered}
\overline{X i}=\frac{\sum_{i=1}^{k} X i}{n} \\
\bar{Y} i=\frac{\sum_{i=1}^{k} Y i}{n}
\end{gathered}
$$

dimana:

$$
\begin{aligned}
& \overline{X i}=\begin{array}{l}
\text { Bobot rata-rata tingkat penilaian kinerja } \\
\text { atribut ke-i }
\end{array} \\
& \overline{Y i}=\begin{array}{l}
\text { Bobot rata-rata tingkat penilaian } \\
\text { kepentingan atribut ke-i }
\end{array} \\
& \mathrm{n}=\text { Jumlah responden }
\end{aligned}
$$

Langkah selanjutnya adalah menghitung ratarata tingkat kepentingan dan kinerja untuk keseluruhan atribut dengan rumus:

$$
\begin{gathered}
\overline{\overline{X i}}=\frac{\sum_{i=1}^{k} \overline{X i}}{n} \\
\overline{\overline{Y i}}=\frac{\sum_{i=1}^{k} \overline{Y i}}{n}
\end{gathered}
$$

dimana:

$\overline{\overline{X i}}=$ Bobot rata-rata tingkat penilaian kinerja atribut ke-i

$\overline{\bar{Y}} i=$ Bobot rata-rata tingkat penilaian kepentingan atribut ke-i

$\mathrm{n}=$ Jumlah atribut

Nilai rata-rata dari skor tingkat kepentingan dan kinerja digunakan untuk menentukan poin-poin yang ada dalam kuadran. Interpretasi selanjutnya merupakan kombinasi dari skor-skor tingkat kepentingan dan kualitas tiap atribut. Hasil analisis meliputi empat saran berbeda berdasarkan ukuran tingkat kepentingan (importance) dan kualitas atau kondisi ruang (performance), yang selanjutnya dapat dipergunakan sebagai dasar untuk menetapkan rekomendasi selanjutnya.

Analisis ini diawali dengan kuesioner yang disebarkan kepada masyarakat Kelurahan Baru Ulu, setiap pertanyaan memiliki dua jawaban dalam skala 1 sampai 5, yaitu apakah menurut masyarakat hal tersebut penting dilakukan atau dilaksanakan dan bagaimana kinerjanya, baik atau tidak baik.

Dengan diagram Kartesius yang merupakan suatu bangun persegi empat bagian yang dibatasi oleh dua buah garis yang berpotongan tegak lurus pada titik-titik $(\mathrm{X}, \mathrm{Y})$, dimana $\mathrm{X}$ merupakan rata-rata dari rata-rata skor kinerja seluruh indikator dan $\mathrm{Y}$ adalah rata-rata dari rata-rata skor tingkat kepentingan seluruh indikator yang memengaruhi harapan sebagaimana penjelasan sebagai berikut:

1. Kuadran IV (Kuadran Prioritas Pertama) menunjukkan faktor-faktor yang dianggap sangat penting, namun bentuk penyediaan 
air bersih belum memenuhi kebutuhan sesuai keinginan atau harapan masyarakat Kelurahan Baru Ulu.

2. Kuadran III (Kuadran Prioritas Rendah) menunjukkan faktor-faktor yang dianggap kurang penting, dan penyediaan air bersih memenuhi kebutuhan masyarakat Kelurahan Baru Ulu secara cukup atau biasa saja.

3. Kuadran II (Kuadran Berlebihan) menunjukkan faktor yang kurang penting tetapi bentuk penyediaan air bersih memenuhi kebutuhan masyarakat Kelurahan Baru Ulu secara berlebihan atau sangat memuaskan.

4. Kuadran I (Kuadran Prestasi) menunjukkan faktor-faktor yang dianggap penting, dan bentuk penyediaan air bersih telah berhasil memenuhi kebutuhan masyarakat dan Kelurahan Baru Ulu sesuai keinginan atau harapan dan sangat memuaskan sehingga wajib dipertahankan.

\section{HASIL DAN PEMBAHASAN}

Terdapat 31 indikator (V) penyediaan air bersih yang diberi nilai untuk tingkat kinerja dan tingkat kepentingan oleh reponden, di antaranya adalah:

1. Warna air

2. Kandungan bakteri dalam air

3. Rasa asin pada air

4. Munculnya lapisan putih berkilau pada air

5. Rasa asam pada air

6. Bau pada air

7. Adanya hewan-hewan kecil dalam air

8. Deras air mengalir

9. Banyaknya jumlah air dari sumber air

10. Banyaknya jumlah air pada penampungan

11. Durasi air mengalir dalam satu hari

12. Durasi air mengalir dalam satu bulan

13. Ketersediaan air di pagi hari

14. Ketersediaan air di sore hari

15. Kemauan masyarakat untuk membayar

16. Kemampuan masyarakat untuk membayar

17. Jarak dari tempat tinggal menuju air bersih

18. Peraturan pengelolaan dari lembaga yang berwenang

19. Adanya keterlibatan kelompok wanita
20. Pengelolaan keuangan

21. Kemampuan masyarakat dalam mengelola air bersih

22. Cakupan pelayanan air bersih dari lembaga pengelola

23. Minat masyarakat dalam mendukung upaya penyediaan air bersih

24. Kemauan masyarakat memiliki sistem penyediaan air bersih yang berkelanjutan

25. Tanggung jawab dan pemeliharaan operasional

26. Adanya kegiatan pengaturan masyarakat

27. Adanya kegiatan pendidikan kesehatan

28. Persetujuan mengenai tarif air

29. Persetujuan mengenai tingkat penyediaan air

30. Kebisingan yang ditimbulkan oleh sistem penyedia air

31. Polusi udara yang ditimbulkan oleh sistem penyedia air.

Evaluasi kinerja penyediaan air bersih di Kelurahan Baru Ulu dilakukan dengan Importance Performance Analysis (Analisis IPA). Analisis IPA mengukur bagaimana kepentingan suatu indikator terhadap kinerja yang selama ini telah berlangsung. Indikatorindikator tersebut dikelompokkan dalam kuadran kartesius. 31 indikator tersebut mendapatkan penilaian kinerja dan kepentingan melalui penyebaran kuesioner pada 99 sampel yang telah ditentukan sebelumnya.

\section{a. Tingkat Kinerja dan Tingkat Kepentingan Indikator Penyediaan Air Bersih di Kelurahan Baru Ulu}

Dalam penelitian ini, sebelum menjabarkan ke dalam diagram kartesius, terlebih dahulu diketahui tingkat kepentingan dan kinerja yang didapat dari rata-rata dari ekspektasi atau tingkat kepentingan dari masingmasing responden tiap indikator $(\mathrm{Y})$ dan ratarata dari persepsi atau kinerja dari masingmasing responden tiap indikator $(\mathrm{X})$. Data tersebut kemudian dijabarkan dalam diagram kartesius, sehingga akan diketahui letak kuadran dari masing-masing atribut. 
Tabel 1. Rekapitulasi hasil pengisian nilai

\begin{tabular}{|c|c|c|c|c|c|c|}
\hline \multirow[b]{2}{*}{ Indikator } & \multicolumn{5}{|c|}{ Nilai Kinerja } & \multirow{2}{*}{$\begin{array}{l}\text { Total } \\
\text { Nilai } \\
\text { Kinerja }\end{array}$} \\
\hline & 5 & 4 & 3 & 2 & 1 & \\
\hline $\mathrm{V}_{1}$ & 6 & 37 & 33 & 16 & 7 & 316 \\
\hline $\mathrm{V}_{2}$ & 4 & 18 & 34 & 19 & 24 & 256 \\
\hline $\mathrm{V}_{3}$ & 6 & 22 & 35 & 20 & 16 & 279 \\
\hline $\mathrm{V}_{4}$ & 4 & 17 & 54 & 16 & 8 & 290 \\
\hline $\mathrm{V}_{5}$ & 5 & 26 & 39 & 12 & 18 & 283 \\
\hline $\mathrm{V}_{6}$ & 3 & 20 & 36 & 20 & 20 & 263 \\
\hline $\mathrm{V}_{7}$ & 18 & 30 & 23 & 12 & 16 & 319 \\
\hline $\mathrm{V}_{8}$ & 4 & 28 & 29 & 26 & 12 & 283 \\
\hline $\mathrm{V}_{9}$ & 9 & 34 & 20 & 30 & 6 & 307 \\
\hline $\mathrm{V}_{10}$ & 13 & 35 & 33 & 11 & 7 & 333 \\
\hline $\mathrm{V}_{11}$ & 12 & 24 & 26 & 21 & 15 & 291 \\
\hline $\mathrm{V}_{12}$ & 11 & 33 & 20 & 27 & 8 & 309 \\
\hline $\mathrm{V}_{13}$ & 14 & 17 & 32 & 21 & 15 & 291 \\
\hline $\mathrm{V}_{14}$ & 12 & 33 & 25 & 19 & 10 & 315 \\
\hline $\mathrm{V}_{15}$ & 22 & 33 & 21 & 12 & 11 & 340 \\
\hline $\mathrm{V}_{16}$ & 20 & 34 & 27 & 9 & 9 & 344 \\
\hline $\mathrm{V}_{17}$ & 22 & 39 & 23 & 9 & 6 & 359 \\
\hline $\mathrm{V}_{18}$ & 10 & 17 & 27 & 25 & 20 & 269 \\
\hline $\mathrm{V}_{19}$ & 3 & 17 & 36 & 23 & 20 & 257 \\
\hline$V_{20}$ & 7 & 28 & 33 & 17 & 14 & 294 \\
\hline $\mathrm{V}_{21}$ & 10 & 32 & 30 & 19 & 8 & 314 \\
\hline $\mathrm{V}_{22}$ & 10 & 29 & 33 & 16 & 11 & 308 \\
\hline $\mathrm{V}_{23}$ & 23 & 33 & 23 & 14 & 6 & 350 \\
\hline $\mathrm{V}_{24}$ & 32 & 26 & 27 & 8 & 6 & 367 \\
\hline $\mathrm{V}_{25}$ & 8 & 28 & 36 & 16 & 11 & 303 \\
\hline$V_{26}$ & 9 & 28 & 37 & 14 & 11 & 307 \\
\hline$V_{27}$ & 7 & 25 & 35 & 16 & 16 & 288 \\
\hline $\mathrm{V}_{28}$ & 9 & 33 & 29 & 13 & 15 & 305 \\
\hline $\mathrm{V}_{29}$ & 12 & 26 & 36 & 11 & 14 & 308 \\
\hline $\mathrm{V}_{30}$ & 22 & 34 & 20 & 7 & 16 & 336 \\
\hline $\mathrm{V}_{31}$ & 27 & 36 & 15 & 7 & 14 & 352 \\
\hline
\end{tabular}

Sumber: Hasil survei, 2017

Pengisian tingkat kinerja diisi oleh 99 responden dari Kelurahan Baru Ulu. Berdasarkan rekapitulasi tersebut, variabel yang memiliki nilai kinerja tertinggi adalah $\mathrm{V}_{17}$ yakni Kemauan Masyarakat untuk Memiliki Sistem Penyediaan Air Bersih yang Berkelanjutan. Hal tersebut berarti bahwa Masyarakat Kelurahan Baru Ulu memiliki kemauan yang sangat besar untuk memiliki penyediaan air bersih yang berkelanjutan dan diiringi dengan upaya-upaya mereka yang berusaha untuk mendapatkan penyediaan air bersih.
Tabel 2. Rekapitulasi Hasil Pengisian Nilai Kepentingan Pada Kuesioner IPA

\begin{tabular}{|c|c|c|c|c|c|c|}
\hline \multirow[b]{2}{*}{ Indikator } & \multicolumn{5}{|c|}{ Nilai Kepentingan } & \multirow{2}{*}{$\begin{array}{l}\text { Total Nilai } \\
\text { Kepentingan }\end{array}$} \\
\hline & 5 & 4 & 3 & 2 & 1 & \\
\hline $\mathrm{V}_{1}$ & 45 & 35 & 14 & 3 & 2 & 415 \\
\hline $\mathrm{V}_{2}$ & 49 & 29 & 12 & 6 & 3 & 412 \\
\hline $\mathrm{V}_{3}$ & 33 & 35 & 28 & 3 & 0 & 395 \\
\hline $\mathrm{V}_{4}$ & 28 & 35 & 24 & 4 & 8 & 368 \\
\hline $\mathrm{V}_{5}$ & 30 & 33 & 21 & 9 & 6 & 369 \\
\hline $\mathrm{V}_{6}$ & 49 & 25 & 18 & 6 & 1 & 412 \\
\hline $\mathrm{V}_{7}$ & 63 & 23 & 6 & 3 & 3 & 487 \\
\hline $\mathrm{V}_{8}$ & 52 & 26 & 14 & 3 & 4 & 416 \\
\hline $\mathrm{V}_{9}$ & 47 & 36 & 10 & 4 & 0 & 421 \\
\hline $\mathrm{V}_{10}$ & 52 & 23 & 16 & 5 & 3 & 413 \\
\hline $\mathrm{V}_{11}$ & 43 & 43 & 6 & 2 & 5 & 414 \\
\hline $\mathrm{V}_{12}$ & 46 & 38 & 9 & 3 & 3 & 418 \\
\hline $\mathrm{V}_{13}$ & 60 & 29 & 6 & 3 & 1 & 441 \\
\hline $\mathrm{V}_{14}$ & 60 & 28 & 6 & 3 & 2 & 438 \\
\hline $\mathrm{V}_{15}$ & 38 & 26 & 23 & 9 & 3 & 384 \\
\hline $\mathrm{V}_{16}$ & 32 & 30 & 20 & 12 & 5 & 369 \\
\hline $\mathrm{V}_{17}$ & 53 & 22 & 17 & 6 & 1 & 417 \\
\hline $\mathrm{V}_{18}$ & 33 & 26 & 19 & 14 & 7 & 361 \\
\hline $\mathrm{V}_{19}$ & 18 & 23 & 27 & 15 & 16 & 309 \\
\hline $\mathrm{V}_{20}$ & 36 & 23 & 24 & 10 & 6 & 370 \\
\hline $\mathrm{V}_{21}$ & 33 & 24 & 23 & 14 & 5 & 363 \\
\hline $\mathrm{V}_{22}$ & 48 & 19 & 19 & 10 & 2 & 395 \\
\hline $\mathrm{V}_{23}$ & 29 & 26 & 26 & 11 & 7 & 356 \\
\hline $\mathrm{V}_{24}$ & 33 & 24 & 22 & 17 & 3 & 364 \\
\hline $\mathrm{V}_{25}$ & 33 & 25 & 25 & 12 & 4 & 368 \\
\hline $\mathrm{V}_{26}$ & 32 & 38 & 19 & 9 & 1 & 388 \\
\hline $\mathrm{V}_{27}$ & 36 & 30 & 20 & 11 & 2 & 384 \\
\hline $\mathrm{V}_{28}$ & 41 & 29 & 19 & 7 & 3 & 395 \\
\hline $\mathrm{V}_{29}$ & 34 & 28 & 26 & 10 & 1 & 381 \\
\hline $\mathrm{V}_{30}$ & 38 & 32 & 20 & 6 & 3 & 393 \\
\hline $\mathrm{V}_{31}$ & 39 & 33 & 17 & 8 & 2 & 396 \\
\hline
\end{tabular}

Sumber: Hasil survei, 2017

Pengisian tingkat kepentingan diisi oleh 99 responden dari Kelurahan Baru Ulu. Berdasarkan rekapitulasi tersebut, variabel yang memiliki nilai kepentingan tertinggi adalah $\mathrm{V}_{7}$ yakni Adanya Hewan-Hewan Kecil yang Hidup pada Air. Hal tersebut berarti bahwa Masyarakat Kelurahan Baru Ulu merasa tidak ingin mendapatkan air yang mengandung hewanhewan kecil di dalamnya.

Dengan menggunakan perhitungan nilai rata-rata dari nilai $\mathrm{X}$ dan $\mathrm{Y}$, didapat bahwa diagram kartesius Kelurahan Baru Ulu mempunyai nilai koordinat $\mathrm{X}$ di titik 3.11 dan nilai koordinat $\mathrm{Y}$ di titik 3.98. 
Pada penelitian ini terdapat dari 2 variabel yang mewakili oleh huruf $\mathrm{X}$ dan $\mathrm{Y}$, dimana $\mathrm{X}$ merupakan tingkat kinerja penyediaan air bersih yang dapat memberikan kinerja bagi masyarakat, sedangkan $\mathrm{Y}$ merupakan tingkat ekspektasi atau kepentingan bagi masyarakat mengenai penyediaan air bersih yang mereka dapatkan.

Diagram kartesius dibuat dengan membagi suatu bagan menjadi empat bagian yang dibatasi oleh dua buah garis yang berpotongan tegak lurus pada titik-titik X, dan Y, dimana $\mathrm{X}$ merupakan rata-rata dari rata-rata nilai tingkat kinerja atas seluruh indikator, sedangkan $\mathrm{Y}$ adalah rata-rata dari rata-rata nilai tingkat kepentingan seluruh indikator yang memengaruhi kinerja masyarakat terhadap penyediaan air bersih yang ada di Kelurahan Baru Ulu.

\section{b. Penjabaran Setiap Indikator dalam Kuadran Kartesius}

Diagram Kartesius merupakan diagram atas empat bagian yang batasi oleh dua buah garis yang berpotongan tegak lurus pada titiktitk X dan Y (Yola \& Budianto, 2013). Diagram kartesius dibuat dengan membagi suatu bagan menjadi empat bagian yang dibatasi oleh dua buah garis yang berpotongan tegak lurus pada titik-titik $\mathrm{X}$, dan $\mathrm{Y}$, dimana $\mathrm{X}$ merupakan ratarata dari rata-rata nilai tingkat kinerja atas seluruh indikator, sedangkan $\mathrm{Y}$ adalah rata-rata dari rata-rata nilai tingkat kepentingan seluruh indikator yang memengaruhi kinerja masyarakat terhadap penyediaan air bersih yang ada di Kelurahan Baru Ulu.

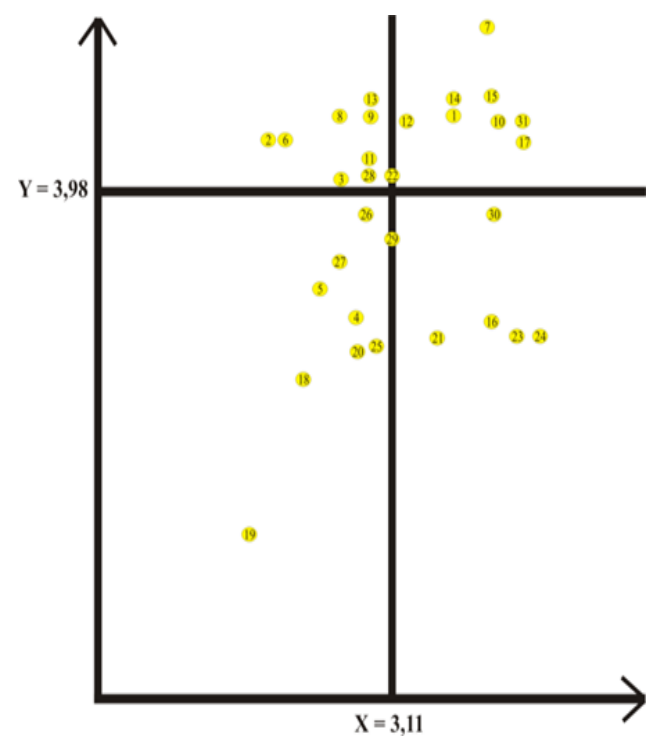

Gambar 1. Diagram Kartesius Penyediaan Air Bersih di Kelurahan Baru Ulu Sumber: Hasil analisis, 2017

Diagram kartesius untuk penyediaan air bersih di Kelurahan Baru Ulu mempunyai $X$ dengan nilai 3.11 dan $Y$ dengan nilai 3.98. Pada diagram tersebut, dapat dilihat bahwa indikatorindikator penyediaan air bersih yang masuk ke dalam Kuadran Prioritas Pertama yang berarti bahwa indikator tersebut mempunyai nilai kinerja rendah namun mempunyai nilai kepentingan tinggi meliputi indikator nomor 2, $3,6,8,9,11,13$, dan 28. Indikator-indikator penyediaan air bersih yang masuk ke dalam Kuadran Prestasi yang berarti bahwa indikator tersebut mempunyai nilai kinerja tinggi dan nilai kepentingan tinggi meliputi indikator nomor 1 , $10,12,14,15,17$, dan 31. Indikator yang masuk ke dalam Kuadran Prioritas rendah yang berarti mempunyai nilai kinerja rendah dan nilai kepentingan yang juga rendah meliputi indikator nomor 4, 5, 18, 19, 20, 25, 26, dan 27. Indikator yang masuk ke dalam Kuadran Berlebihan yang berarti bahwa indikator tersebut mempunyai nilai kinerja tinggi namun mempunyai nilai kepentingan rendah meliputi indikator nomor $16,21,23,24,29$, dan 30 . 
Berdasarkan pengelompokan indikator tersebut, dapat dilihat bahwa masyarakat Kelurahan Baru Ulu menilai bahwa terdapat 8 indikator yakni kandungan bakteri dalam air, rasa asin pada air, bau pada air, deras air mengalir pada setiap rumah, banyaknya jumlah air yang ada dari sumber air, durasi air mengalir dalam satu hari, ketersediaan air di pagi hari, dan persetujuan mengenai tarif air yang harus dibayar mempunyai nilai kinerja rendah namun tingkat kepentingannya tinggi.

\section{c. Hasil Evaluasi Kinerja Penyediaan Air Bersih di Kelurahan Baru Ulu}

Evaluasi kinerja penyediaan air bersih di Kelurahan Baru Ulu menunjukkan hasil klasifikasi indikator prinsip penyediaan air bersih berdasarkan tingkat kinerja dan tingkat kepentingan. Masing-masing indikator prinsip penyediaan air bersih memiliki penilaian terhadap tingkat kinerja dan tingkat kepentingan. Oleh karena itu, klasifikasi dibagi menjadi indikator prinsip penyediaan air bersih yang memiliki kinerja rendah dan kepentingan tinggi, kinerja tinggi dan kepentingan tinggi, kinerja rendah dan kepentingan rendah, serta kinerja tinggi dan kepentingan rendah.

Hasil evaluasi penyediaan air bersih di Kelurahan Baru Ulu menunjukkan bahwa indikator yang mempunyai kinerja rendah dan kepentingan tinggi meliputi kandungan bakteri dalam air, rasa asin pada air, bau pada air, deras air mengalir, banyaknya jumlah air dari sumber air, durasi air mengalir dalam satu hari, ketersediaan air di pagi hari, dan persetujuan mengenai tarif air. Hal tersebut menunjukkan bahwa masyarakat Kelurahan Baru Ulu sangat tidak puas terhadap kualitas fisik dan kuantitas air. Menurut Parera (2013), air yang relatif dekat dengan permukaan tanah lebih mudah terkena kontaminasi bakteri melalui rembesan yang berasal dari tempat pembuangan kotoran manusia maupun limbah dari sumber air.

Indikator yang mempunyai kinerja tinggi dan kepentingan tinggi meliputi warna air, banyaknya jumlah air yang ada pada penampungan, durasi air mengalir dalam satu bulan, ketersediaan air di sore hari, kemauan masyarakat membayar untuk mendapatkan air bersih, jarak dari tempat tinggal menuju akses air bersih, cakupan pelayanan, dan polusi udara yang ditimbulkan oleh sistem penyedia air bersih. Dari hasil tersebut dapat dikatakan bahwa masyarakat Kelurahan Baru Ulu telah sangat puas dengan kualitas kekeruhan air, finansial, dan aksesibilitasnya. Air akan mengalami kekeruhan apabila air tersebut mengandung begitu banyak partikel bahan yang tersuspensi sehingga memberikan warna atau rupa yang berlumpur dan kotor (Oviantari, 2011). Terkait aksesibilitas, sistem distribusi air bersih memiliki cakupan pelayanan yang berbeda di setiap daerah pelayanan. Hal ini disebabkan oleh perbedaan kemampuan sumber air baku yang menyuplai kebutuhan air bersih pelanggan (Wardhana et al, 2013).

Indikator yang mempunyai kinerja rendah dan kepentingan rendah meliputi lapisan putih berkilau pada permukaan air, rasa asam pada air, peraturan dari pengelola, adanya keterlibatan kelompok wanita, pengelolaan keuangan, tanggung jawab dan pemeliharaan, adanya kegiatan pengaturan masyarakat, dan adanya kegiatan pendidikan kesehatan. Klasifikasi terakhir adalah indikator yang memiliki kinerja tinggi dan kepentingan rendah meliputi kemampuan masyarakat membayar, kemampuan masyarakat dalam pengelolaan air, minat masyarakat dalam mendukung upaya penyediaan air bersih, kemauan masyarakat memiliki penyediaan air bersih, persetujuan mengenai tingkat penyediaan air bersih, dan kebisingan yang ditimbulkan oleh penyedia air bersih.

Berdasarkan penelitian yang telah dilakukan oleh Noviyanti dan Setiawan (2014), terdapat enam indikator yang menjadi hal yang sangat penting dalam penyediaan air bersih di kawasan pesisir. Enam indikator tersebut di antaranya meliputi kepadatan penduduk, alokasi dana peningkatan air bersih, jarak sumber air bersih terhadap permukiman, jumlah sumber air, debit sumber air, dan kelerengan sumber air bersih. Penelitian tersebut dilakukan di kawasan pesisir Kabupaten Lamongan. Dengan dilakukan perbandingan mengenai indikator penting 
tersebut, maka didapatkan hasil bahwa indikator yang dianggap penting dalam suatu upaya penyediaan air bersih antar kawasan pesisir berbeda satu sama lain. Setiap kawasan pesisir masing-masing memiliki indikator penting yang berbeda-beda.

Berdasarkan penelitian yang telah dilakukan oleh Saniti (2012), indikator yang berkaitan dengan lingkungan dan kelembagaan merupakan aspek yang paling memengaruhi penyediaan air bersih berkelanjutan di wilayah pesisir. Hal ini menggambarkan bahwa penyediaan air bersih yang diselenggarakan di wilayah pesisir harus mampu memenuhi kebutuhan masyarakat, khususnya dari aspek kualitas dan kontinuitas air serta aspek kelembagaan. Ketiga indikator ini merupakan hal yang harus dipenuhi oleh suatu alternatif sistem air bersih wilayah pesisir. Berdasarkan hasil evaluasi yang telah didapatkan dari Kelurahan Baru Ulu, yang mana masyarakat tidak menganggap penting indikator kelembagaan, maka didapat bahwa masyarakat Kelurahan Baru Ulu tidak memprioritaskan prinsip keberlanjutan dalam hal penyediaan air bersih.

Dari masing-masing penilaian kinerja dan kepentingan, didapat bahwa masyarakat Kelurahan Baru Ulu mempunyai kemampuan yang sangat baik untuk membayar tarif yang dikenakan air bersih demi mendapatkan jumlah air serta kualitas air yang memadai.

\section{KESIMPULAN DAN SARAN}

Di Kelurahan Baru Ulu, indikator penyediaan air bersih yang memiliki kepentingan tinggi yang disertai kinerja rendah meliputi kandungan bakteri dalam air, rasa asin pada air, bau pada air, deras air mengalir, banyaknya jumlah air dari sumber air, durasi air mengalir dalam satu hari, ketersediaan air pada pagi hari, dan persetujuan mengenai tarif air yang dibayar. Artinya, kepuasan terhadap delapan indikator tersebut sangat rendah dibandingkan dengan ekspektasi masyarakat kawasan tersebut. Sehingga, delapan indikator tersebut dapat dijadikan sebagai prioritas utama dalam perumusan upaya penyediaan air bersih di Kelurahan Baru Ulu untuk mencapai target pemenuhan air bersih $100 \%$ pada tahun 2030 sesuai dengan target yang terdapat dalam Rencana Tata Ruang Wilayah Kota Balikpapan Tahun 2012 hingga 2032.

Berdasarkan penelitian ini, saran yang dapat diberikan kepada pemerintah ialah dalam penyediaan air bersih, masyarakat ikut diturutsertakan dalam kinerjanya. Masyarakat dapat diberi kesempatan untuk mengambil keputusan, memberikan ide, serta mengevaluasi kinerja pemerintah dan juga kinerja swadaya masyarakat.

\section{DAFTAR PUSTAKA}

Afrilya, F., \& Rahmawati, A. (2014). Program Penyediaan Air Minum Berbasis Masyarakat di Desa Tiris Kecamatan Tiris Kabupaten Probolinggo. Artikel Ilmiah Hasil Penelitian Mahasiswa Universitas Jember, 1-13.

Arimbi, D. (2015). Evaluasi Kinerja Penyediaan Air Bersih di Kelurahan Sukolilo, Surabaya. Jurnal Teknik POMITS, 1-10.

Badan Perencanaan dan Pembangunan Daerah Kota Balikpapan. (2016). Rencana Tata Ruang Wilayah Kota Balikpapan 2012 2032.

Badan Pusat Statistik Kota Balikpapan. (2016). Kecamatan Balikpapan Barat dalam Angka 2016.

Lestari, A. S., Aditiajaya, Widianingsih, E., \& Dharmawan, H. (2009). Monitoring Kualitas Air Oleh Masyarakat. Jakarta: USAID.

Mwakila, W. (2008). An Assessment of Community Participation in Water Supply and Sanitation Services: The Case of Yombo Dovya and Barabara ya Mwinyi, Water Community Projects, Temeke, Tanzania. The Hague: Institute of Social Studies.

Noviyanti, E., \& Setiawan, R. P. (2014). Penyediaan Air Bersih pada Kawasan Rawan Air Bersih di Pesisir Utara Lamongan. Tata Loka, 117-132. 
Oviantari, M. V. (2011). Analisis Indek Kualitas Air Pada Mata Air Tlebusan Baluan, Pancoran Camplung, dan Pancoran Padukuhan di Banjar Cau, Tabanan. Jurnal Seminar Nasional FMIPA Undiksha, 252-259.

Parera, M., Supit, W., \& Rumampuk, J. (2013). Analisis Perbedaan Pada Uji Kualitas Sumur di Kelurahan Madidir Ure Kota Bitung Berdasarkan Parameter Fisika. Jurnal e-Biomedik 1(1), 466-472.

Saniti, D. (2012). Penentuan Alternatif Sistem Penyediaan Air Bersih Berkelanjutan di Wilayah Pesisir Muara Angke. Jurnal Perencanaan Wilayah dan Kota, 23(3), 197-208.

Santono, H. (2010). Air Bersih dan Sanitasi sebagai Kebijakan Sosial. Jakarta: Komunitas Indonesia untuk Demokrasi.

Sinulingga. (2013). Analisis Kinerja Pelanggan Pada PDAM Tirtasari. Medan: Universitas Sumatera Utara.

Wardhana, I. W., Budiharjo, M. A., \& Adhesti, S. (2013). Kajian Sistem Penyediaan Air Bersih Sub Sistem Bribin Kabupaten Gunungkidul. Jurnal PRESIPITASI, 1(1), 18-29.

Yola, M., \& Budianto, D. (2013). Analisis Kepuasan Konsumen Terhadap Kualitas Pelayanan dan Harga Produk Pada Supermarket Dengan Menggunakan Metode Importance Performance Analysis (IPA). Jurnal Optimasi Sistem Industri, 12(12), 301-309.

Yuliani, Y., \& Rahdriawan, M. (2014). Kinerja Pelayanan Air Bersih Berbasis Masyarakat di Tugurejo Kota Semarang. Jurnal Pembangunan Wilayah \& Kota, 249-264. 